May 2020

\title{
Intercultural Competence for Community College Librarians
}

Phyllis Pistorino

San Jose State University, sussurat@gmail.com

Follow this and additional works at: https://scholarworks.sjsu.edu/ischoolsrj

Part of the Library and Information Science Commons

\section{Acknowledgements}

I would like to thank Dr. Debra Buenting for her fabulous course INFO 281- Intercultural Communication and for all that I learned through her teachings and the experiences shared by my fellow students.

\section{Recommended Citation}

Pistorino, P. (2020). Intercultural Competence for Community College Librarians. School of Information Student Research Journal, 10(1). https://doi.org/10.31979/2575-2499.100107 Retrieved from https://scholarworks.sjsu.edu/ischoolsrj/vol10/iss1/7

This article is brought to you by the open access Journals at SJSU ScholarWorks. It has been accepted for inclusion in School of Information Student Research Journal by an authorized administrator of SJSU ScholarWorks. For more information, please contact scholarworks@sjsu.edu. 


\title{
Intercultural Competence for Community College Librarians
}

\begin{abstract}
As populations grow more diverse and different cultural identities become increasingly prevalent, intercultural competence will be a requirement for successful communication and cultural harmony. Community colleges host the most diverse population of students in the United States, often considered a reflection of the communities they serve. As centers of institutional learning, libraries at community colleges have a responsibility and an opportunity to provide service grounded in the tenets of intercultural competence. These service standards are having and following a diversity policy; providing a welcoming and accessible environment; offering services and materials that match students needs and backgrounds; communicating in a way that is "culturally humble;" and lastly, hiring practices that ensure a diverse staff.
\end{abstract}

\section{Keywords}

Community College; Libraries; Intercultural Competence; Students; Information Needs

\section{Acknowledgements}

I would like to thank Dr. Debra Buenting for her fabulous course INFO 281- Intercultural Communication and for all that I learned through her teachings and the experiences shared by my fellow students.

\section{About Author}

Phyllis Pistorino is an editor, librarian, and emerging researcher living in New Orleans, LA. She attended San José State University for her Master's in Library and Information Science, class of 2020. 
Community colleges are some of the most diverse higher education institutions in the U.S. Students vary in age, ethnicity, religion, educational background, and ability. They also differ in educational pathways from other traditional higher education institutions as the student body are involved in different pursuits all on the same campus. Community colleges offer associates or transfer degrees, but also adult continuing education, ESL, and vocational training programs. Students at community colleges differ from those at other colleges or universities, so information needs also diverge among the student body.

Libraries and librarians at community colleges play a unique role in providing a spectrum of information literacy instruction, reference, and circulation of materials to meet the needs of their diverse student patrons. Community college librarians must internalize deeper sensitivity, as well as awareness and cultural competency in their interactions with the student body. While providing high-level service to student patrons, librarians should create a welcoming, approachable, and usable space where differences are respected and students feel confident to access services.

This paper will first examine the main differences between community college and other higher learning student bodies and their information needs. A discussion of the purpose of the community college library will show the emphasis on supporting current curriculum, as opposed to supporting research as at other academic libraries (Dowell, 2006). Next, the basic tenets of intercultural competence will be discussed, followed by a section detailing trends in cultural competence in the wider field of librarianship. Then the discussion will delve into the many ways in which librarians at community colleges must embrace intercultural competence as the pathway to successful reference, circulation, and literacy instruction for their multicultural patrons. Resulting from research and best practices from around the field of librarianship and higher education, a detailed five-step plan is included to help librarians at community colleges achieve intercultural competence.

\section{Community Colleges: It's All About Students}

Community and junior colleges can be traced back to the late $19^{\text {th }}$ and early $20^{\text {th }}$ century United States, born out of necessity for educational opportunities and vocational training in smaller towns, and a growing belief that education should be accessible to everyone (Crumpton \& Bird, 2013). Traditionally, community colleges were vocational or technical training centers, while junior colleges provided a bridge between high school education and universities. The Great Depression and World War II exposed an even further need for university preparation and vocational training, so the importance of community and junior colleges increased, with expansion active into the 1960s. The separate functionalities of the two systems remained largely in place until the 1990s, when funding pressure from governments caused a movement of two-year schools to adopt the community college designation, with the dual-mission of vocational training and university preparation (Crumpton \& Bird, 2013). 
Today, community colleges are a reflection of the communities they serve. They remain tied to the needs of their individual regions, and are therefore more affected by economic, demographic, and population trends than other secondary education institutions. As David Dowell (2006) writes in the foreword to It's All About Student Learning, community colleges are increasingly "becoming vehicles for lifelong learning as they approach their potential to provide education by the community, for the community, and in the community" (p. ix) In this way, community college libraries are truly all about the students and less about creating or supporting institutional research, as other academic libraries are required in order to achieve relevancy (Dowell, 2006).

Because of the diverse nature of community college students, information needs will also be unique. In traditional higher education institutions, most students will be beyond basic literacy instruction, have a rudimentary understanding of research concepts, and a grasp on the function of available resources. Information needs of a typical community college student will vary wildly because of nontraditional ages, ethnic, language, and cultural differences, as well as disparities in learning and physical ability (Crumpton \& Bird, 2013). The typical community college student will not have a computer at home, have little to no computer literacy skills, such as using word processing programs or converting files, have poor information management skills, lack a quiet place to study at home, and may be coming from low-performing schools (Godin, 2006). Compounded by the cultural differences referenced above, librarianship in community college can be complicated and requires excellent communication and perceptive leadership.

Community college libraries exist to support college curriculum, so the services and collections should be designed to enhance learning (Dowell, 2006). If the collection of services and materials are to appropriately reflect the community of students, libraries must be attractive and comfortable, and librarians must strive to be approachable and in many cases, seek out opportunities to create connections. Librarians at community colleges face unique challenges in serving these diverse populations, and must be exceptionally culturally competent in order to provide equal access, engage students, and affect learning.

\section{Intercultural Competence}

\section{What is Intercultural Competence?}

Modern life is increasingly affected by intercultural mixing. The world, and specifically the United States, is currently undergoing the most extensive trend of cultural mixing in recorded history (Lustig \& Koester, 2013). By 2050, population breakdowns will no longer show a majority of Christian European Americans in the U.S., and even now, people are more comfortable identifying with several cultural values and characteristics than ever before, which will continue to largely affect how we interact and communicate with each other (Lustig \& Koester, 2013).

There is widespread recognition that intercultural competence is imperative for national and global economic, technological, interpersonal, and 
peace concerns (Lustig \& Koester, 2013). Intercultural competence can be defined as the ability of an individual to function well within a culturally diverse and global society. They need to be able to interact in "meaningful, appropriate, and effective ways with others" (Riley, Bustamante, \& Edmonson, 2016, p. 35). Achieving competence in this way depends upon an individual's ability to understand the role of culture in communication.

All communication is built on a foundation of basic characteristics. Communication is a symbolic, contextual, and transactional process by which people build shared meanings (Lustig \& Koester, 2013). For example, cultures that are high-context will communicate through symbolism, understood meanings, and settings as opposed to low-context cultures that communicate through direct verbal interactions. People who are culturally competent will recognize and respect the subtle differences in various communication styles from different cultures, as well as learn to embody those styles to enhance their interactions with other individuals. This will require a person to be self-reflective and also willing to explore and celebrate the different cultural values of those around them. Gaining a deeper understanding of why or how individuals communicate will allow for greater functionality within our increasingly global society.

\section{Librarianship and Intercultural Competence}

The value of intercultural competence for librarians has been extensively analyzed and affirmed, specifically in public librarianship where multicultural patrons are the norm. A quick look at a research database will pull thousands of studies, books, and articles that illustrate the need for culturally competent library staff, and looking at the American Library Association (ALA) or other related organization's websites will show guidelines and articles about multiculturalism in libraries. The Association of College and Research Libraries (ACRL) published a list of 11 diversity standards in 2012, noting that if libraries are to effectively serve the communities they represent, they "have to open their arms to all perspectives and experiences. That requires competency in matters of cultural pluralism that are not intuitive and must be learned, like any other essential skill" (para. 4). As noted in the standards, diversity is now more than a moral imperative, and is considered a global necessity.

According to Reed (2017), all academic librarians are teachers. Librarians who are trained in cultural competence will have the tools and power to help students from diverse backgrounds achieve educational success by providing an environment that allows the student to feel accepted. Creating surroundings where students are comfortable, not only in accessing the building and materials, but also in asking questions, is imperative in encouraging use by intercultural student patrons. Danielle and Sean Colbert-Lewis' (2013) article in Library Services for Multicultural Patrons outlined two important concepts in making school libraries a place of belonging: freedom and security. Students need a safe place to learn, explore new ideas, and most importantly, expand self-development. There needs to be a connection to their everyday lives and personal identities, social constructs, and relational values. Research discussed in Boelens, Cherek, Tilke, and Bailey (2015) found similar results. According to their study, student patrons cannot begin learning until they feel "safe, seen, and valued" (para. 7), and that 
learning is significantly diminished when equity and diversity topics are not addressed.

Another distinctive study approached the topic of multicultural patrons and libraries by proposing that comparing library services to hospitals could decrease "library anxiety" (Buck \& Houzé, 2014). The study found that hospitals are developing healing spaces that aim to decrease anxiety in patients and increase whole healing. Their study discovered that especially among multicultural patrons, library avoidance occurs because of potential language barriers, confusing cultural patterns, and an unfamiliar, overwhelming research atmosphere. Basically, libraries cause anxiety for multicultural patrons. They suggested libraries could practice "cultural responsiveness" by approaching multicultural users as individuals instead of cultural monoliths. Library anxiety can be overall decreased by facilitation of culturally safe and free spaces. Finally, their study suggested that cultural differences should not be the focus of libraries, but rather communication, shared meanings, and cultural humility (Buck \& Houzé, 2014).

\section{Practical Application}

\section{Intercultural Competence in the Community College Library}

Application of diversity standards or multicultural approaches to librarianship will vary by institution. As noted in previous sections, community colleges are unique in student population, and therefore information needs. Application of intercultural competence in community college libraries requires significant planning, foresight, and a mindset focused on student success. As explored above, students who feel valued, comfortable, and experience a sense of safety and freedom will engage more with the learning environment. Therefore, it is the responsibility of community college library staff to achieve cultural competence to serve their student needs.

There are five steps staff at these libraries can take to reach their goal of a useable and engaging atmosphere. First, the focus should be on developing and following diversity standards. Second, the actual library building should be welcoming, bright, and open, with study nooks and accessible materials. Third, materials and services should be evaluated to ensure they are meeting student and faculty needs and wants. Fourth, reference and information literacy instruction should be conducted in a "culturally humble" manner, where the librarian considers the cultural background of the student and adjusts, so that service is not a "one fits all" or monolithic approach. Fifth, and perhaps most importantly, staff should also be diverse! Below follows a further discussion of these five steps toward a culturally competent community college library.

Following diversity standards, such as those produced by ACRL (2012), will allow for cohesive and strong internal policy development, which ensures there is support for future changes or challenges. Providing guidelines to staff will also have a twofold effect: staff who may have issues with cultural differences will understand there are set behavioral expectations, while staff who may themselves be culturally diverse will feel supported. Having procedural guidelines and managing principles will also prove valuable as evidence to faculty and 
college administration to ensure monetary and administrative support (Downing, MacAdam, \& Nichols, 1993).

The library building and layout, which is the second step, should endeavor to lighten "library anxiety," as referenced in Buck and Houzé's 2014 study. This includes anything that is sensory, such as lighting, temperature, and noise levels, as well as décor, ambiance, and spatial considerations. It should account for human interactions and relationships in the learning environment; overall, the space shouldn't scream academia, which can be intimidating for a variety of reasons. Students from cultural backgrounds that have large power-distance orientation might view an overly formal and academic atmosphere as a place where questions aren't welcome and authority figures shouldn't be approached (Lustig \& Koester, 2013). That would be the very antithesis of what a community college library should symbolize.

The third step, circulation, including the materials and services provided by the library and staff, should reflect the needs of student patrons and consider their backgrounds for further enrichment. For example, monolingual collections that lack appropriate intercultural materials such as ethnically and culturally diverse subject matter or authors could alienate student patrons who don't see representation. Further, students who are uncomfortable with databases or Internet resources might benefit from more analog materials and reserve copies of textbooks (Godin, 2006). Frequently changing displays that showcase materials or research resources that may appeal to a wide breadth of students will also encourage interaction with and exploration of the library as a place.

Services, such as reference and information literacy instruction, should be conducted with utmost sensitivity and respect. This fourth step deals largely in communication. These more personal interactions between student patrons and librarians are where things can get touchy and communication issues arise. For example, if a student's primary language is a listener-responsible speaking style, as opposed to the English speaker-responsible speaking style, communication breakdowns can occur as soon as a student poses their first question: the student will expect the librarian to infer their meaning, while the English-speaking librarian will expect the student to explicitly state their query (Lustig \& Koester, 2013). Another issue with reference and information literacy instruction is the assumption of librarians that academic and library jargon will translate and make sense to a student (Buck and Houzé, 2014). The culturally competent librarian will strive to use interpretive language and draw out student's issues with investigative questions.

Finally, the fifth step is cultivating diverse staff. According to McBride and Shao (2013), students do best when they see themselves reflected on campus, and may avoid librarians, and even the library as a whole if staff are not representative of the campus population. Librarians from diverse backgrounds will have a positive impact on students and library policies, and be able to provide deeper understanding culturally, racially, and linguistically. As the ACRL (2012) standards relate, in a diverse library, patrons can find someone to relate to and gain the services they need in a way they prefer.

\section{Conclusion}


As explored, community colleges experience higher levels of diversity and multicultural student bodies as compared to other secondary education institutions. Because of this, information needs diverge not only because of ability, ethnicity, age, cultural, and linguistic differences among the population, but also because of the diverse educational pathways offered at these two-year colleges.

Intercultural competence is already a widely valued learned skill among librarianship, but community college libraries and their staff specifically can benefit from following the steps outlined in this paper. First, a diversity standard or policy will allow for institutional growth and planning. Second, the library building and layout should decrease student "library anxiety" by providing a welcoming and accessible environment. Third, the materials and services should reflect student needs and cultural backgrounds. Fourth, communication interactions in reference and information literacy instruction should be approached with a "culturally humble" attitude, with the goal being a transactional conversation. Fifth, and last, the staff at the library should reflect culturally and ethnically diverse populations so that student patrons feel able to relate and gain the services they need.

As populations grow more diverse and individuals reflect more culturally different identities, intercultural competence will be a requirement for successful communication and cultural harmony. Especially in community colleges, which are affected more heavily by demographic trends in the communities they serve, these competencies will be more than a method of survival, but also a chance for personal and societal growth. Librarians working at community colleges have a responsibility, and an opportunity, to provide excellent and lasting learning services to their diverse student patrons by embodying intercultural competence. 


\section{References}

Association of College and Research Libraries. (2012). "Diversity Standards: Cultural Competency for Academic Libraries." Retrieved from http://www.ala.org/acrl/standards/diversity

Becnel, K., \& Smallwood, C. (2013). Library Services for Multicultural Patrons: Strategies to Encourage Library Use. Lanham, Md: Scarecrow Press. Retrieved from http://search.ebscohost.com.delgado.idm.oclc.org/login.aspx?direct=true \&db=nle bk\&AN=494454\&site=ehost-live

Boelens, H., Cherek, J., Tilke, A., \& Bailey, N. (2015). Communicating across cultures: Cultural identity issues and the role of the multicultural, multilingual school library within the school community. Paper presented at International Association of School Librarianship, Maastricht, Netherlands.

Buck, V., \& Houzé, A. (2014). Healing library anxiety: How comparing libraries to hospitals can improve service to multicultural populations. Retrieved from http://library.ifla.org/854/1/221-buck-en.pdf

Colbert-Lewis, D., \& Colbert-Lewis, S. (2013). The role of teacher-librarians in encouraging library use by multicultural patrons. In Becnel, K., \& Smallwood, C. (Eds.), Library Services for Multicultural Patrons: Strategies to Encourage Library Use (pp. 73-81). Lanham, Md: Scarecrow Press. Retrieved from http://search.ebscohost.com.delgado.idm.oclc.org/login.aspx?direct=true \&db=nle bk\&AN=494454\&site=ehost-live

Crumpton, M., \& Bird, N. (2013). Handbook for Community College Librarians. Santa Barbara: ABC-CLIO, LLC.

Dowell, D., \& McCabe, G. (2006). It's All About Student Learning: Managing Community and Other College Libraries in the $21^{\text {st }}$ Century. Westport, CT: Libraries Unlimited.

Downing, K., MacAdam, B., \& Nichols, D. (1993). Reaching a Multicultural Student Community: A Handbook for Academic Librarians. Westport, CT: Greenwood Press.

Godin, C. (2006). New Demographics Mean New Services. In Dowell, D., \& McCabe, G. (Eds.), It's All About Student Learning: Managing Community and Other College Libraries in the $21^{\text {st }}$ Century. Westport, CT: Libraries Unlimited.

Lustig, M., \& Koester, J. (2013). Intercultural Competence: Interpersonal Communication Across Cultures, $7^{\text {th }}$ ed. Boston: Pearson.

McBride, K., \& Shao, X. (2014). Serving diverse populations. . In Becnel, K., \& Smallwood, C. (Eds.), Library Services for Multicultural Patrons: Strategies to Encourage Library Use (pp. 73-81). Lanham, Md: Scarecrow Press. Retrieved from http://search.ebscohost.com.delgado.idm.oclc.org/login.aspx?direct=true $\& d b=n l e$ bk\&AN=494454\&site=ehost-live

Reed, M. (2018). Creating learning opportunities in open education: An exploration of the intersections of information literacy and scholarly communication. In Wesolek, A., Lashley, J., and Langley, A., (Eds.), OER: A Field Guide for Academic Librarians. Pacific University Press. 
Riley, R., Bustamante, R., \& Edmonson, S. (2016). Intercultural competence and student engagement of U.S. community college Students: a mixed method study. Community College Journal of Research and Practice, 40(1), 34-46, DOI: $10.1080 / 10668926.2014 .961588$ 